\title{
CRITICAL DISTANCE BETWEEN THE CARTILAGINOUS EUSTACHIAN TUBE AND THE INTERNAL CAROTID ARTERY
}

Heidi Olander

Syventävien opintojen kirjallinen työ Tampereen yliopisto Lääketieteen ja biotieteiden tiedekunta Syyskuu 2017 
Tampereen yliopisto

Lääketieteen ja biotieteiden tiedekunta

\section{OLANDER HEIDI: CRITICAL DISTANCE BETWEEN THE CARTILAGINOUS EUSTACHIAN TUBE AND THE INTERNAL CAROTID ARTERY}

Artikkeli, $14 \mathrm{~s}$.

Ohjaaja: LT Ilkka Kivekäs

Kirjoittajat: Olander Heidi, Järnstedt Jorma, Poe Dennis, Kivekäs Ilkka Julkaistu: European Archives of Oto-Rhino-Laryngology, 6/2016 (verkko), 1/2017 (painettu lehti) Avainsanat: korvatorven toimintahäiriöt, anatomia

Korvatorven toimintahäiriöt voidaan jakaa kahteen luokkaan: avoin korvatorvi ja korvatorven avautumisen häiriö. Viimeisen vuosikymmenen aikana näitä korvatorven toimintahäiriöitä on hoidettu enenevässä määrin erilaisilla endoskooppisen kirurgian menetelmillä, kuten laserilla, korvatorven pallolaajennuksella ja mikropuhdistuksella, lupaavin hoitotuloksin. Hoito kohdistuu lähinnä korvatorven rustoiseen osaan, joka sijaitsee lähellä sisempää kaulavaltimoa. Tämän tutkimuksen tarkoituksena on selvittää endoskooppisen kirurgian turvallisuutta arvioimalla korvatorven rustoisen osan anatomista sijoittumista sisempään kaulavaltimoon nähden. Alueen tarkka anatominen tuntemus on kirurgille tärkeää, jotta pystytään välttämään leikkauskomplikaatioita, jotka voivat olla jopa henkeä uhkaavia, kuten aivoverenkierron häiriöt ja sisemmän kaulavaltimon repeämä.

Tutkimuksessa korvatorven rustoisen osan luumenin ja sisemmän kaulavaltimon etäisyyttä mitattiin pään magneettikuvista kolmelta tasolta: (a) luisen ja rustoisen korvatorven liitoskohdan, (b) rustoisen korvatorven puolivälin ja (c) korvatorven nenänielun suuaukon tasolta. Tutkimusta varten Tampereen yliopistollisen sairaalan lääketieteellisestä tietokannasta käytiin läpi yhteensä 229 potilaan pään magneettikuvat, joista lopulta tutkimukseen otettiin mukaan 100 tapausta, jotka olivat erotuskyvyltään riittävän tarkkoja mittausten suorittamiseen. Mitat otettiin molemmilta puolilta eli 100 potilaalta yhteensä 200 korvatorvesta. Keskimääräiset mitat tasoille olivat: $A=4.3 \mathrm{~mm}$ (vaihteluväli 1.6-10.4 mm), B=25 mm (vaihteluväli 9.0-61.6 mm) ja C=62 mm (vaihteluväli 34.3-84.4 mm).

Rustoisen korvatorven etäisyys sisempään kaulavaltimoon nenänielun päässä on siis melko suuri, mutta se pienenee huomattavasti mentäessä kohti luisen ja rustoisen korvatorven liitoskohtaa. Yksilöiden välillä etäisyydessä on myös merkittävää vaihtelua. Potilaille, joilla ei ole synnynnäisiä pään alueen rakennepoikkeavuuksia, näyttäisi olevan turvallista tehdä kirurgisia toimenpiteitä korvatorven nenänielun puoleisen pään läheisyydessä. Leikkauskomplikaatioiden riskit kasvavat, mitä lähemmäksi korvatorven liitoskohtaa toimenpiteet ulottuvat, sillä tällöin korvatorvi ja sisempi kaulavaltimo kulkevat koko ajan lähempänä toisiaan. 


\section{TABLE OF CONTENTS}

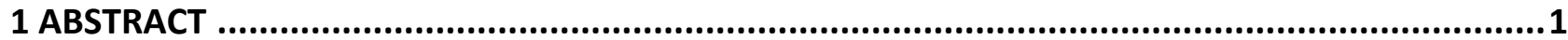

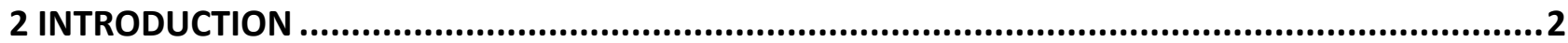

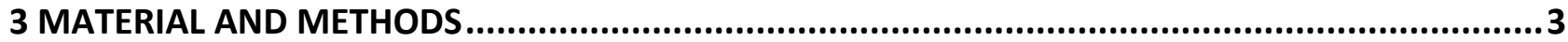

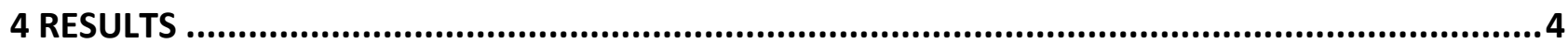

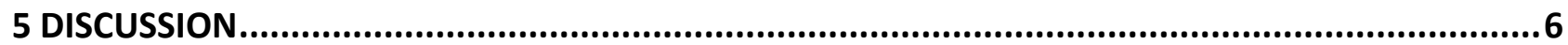

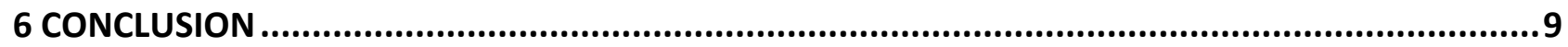

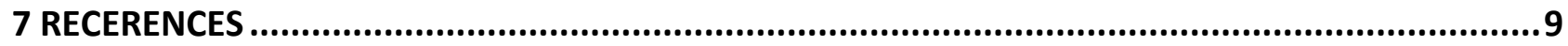





\section{Abstract}

During the last decade endoscopic surgery of the Eustachian tube (ET) has been advocated for ET dilatory dysfunction and for patulous ET. The internal carotid artery (ICA) and the ET are closely related and knowledge of their surgical anatomy has become essential. The present study was designed to establish the anatomical relationships between the endoscopically critical area along the full length of the cartilaginous ET and its closest association with the ICA. The perpendicular distance between the ET lumen and the ICA were measured from head magnetic resonance images (MRI) at three levels: A) cartilaginous and bony ET junctional point, B) mid cartilaginous ET point and C) the nasopharyngeal orifice of the cartilaginous ET.

Totally 200 sides were reviewed in MRI scans of 229 patients. The mean distances for each level were: $\mathrm{A}=4.3 \mathrm{~mm}$ (range $1.6-10.4 \mathrm{~mm}$ ), $\mathrm{B}=25 \mathrm{~mm}$ (range $9.0-61.6 \mathrm{~mm}$ ) and $\mathrm{C}=62 \mathrm{~mm}$ (range 34.3-84.4 mm).

The perpendicular distance between ET and ICA at the nasopharyngeal orifice is large, but the distance shortens quickly while moving from the nasopharyngeal orifice of the ET to the junctional point of the ET. The potential for complications to the ICA rises as the surgical field moves closer to the isthmus of the ET because of the decreasing distance between the ET and the ICA. 


\section{Introduction}

Eustachian tube (ET) dysfunction can be divided into two categories; ET dilatory dysfunction (ETDD) and patulous Eustachian tube (pET). In most cases, the pathology is located in the cartilaginous portion of the ET. The prevalence of ETDD has been reported to be roughly $1 \%$ in the adult population [1]. pET is relatively uncommon ET dysfunctional finding and the prevalence is not known.

During the last decade, endoscopic surgery of the ET has increased for the treatment of ETDD and pET. Initial results of laser, microdebrider and balloon dilation of the ET have been encouraging [2, 3, 4]. Also, endoscopic treatment of pET has been introduced, but results has been limited [5]. Endoscopic approach to the ET provides a good view of the local pathology and anatomical structures. Before the era of endoscopic ET surgery, more robust open surgical approaches were used for ET disorders. Surgical outcomes were poor and complications were severe, including internal carotid artery (ICA) injury with bleeding and some deaths were the main reasons these extensive surgeries were abandoned [6].

Eustachian tube dilation and pET surgery have received increasing attention as safe and potentially effective surgical options for patients with ETDD and pET. To prevent potential severe complications with these approaches, extensive knowledge of the detailed anatomical relationships between the cartilaginous ET and the ICA is needed. Previous studies of this anatomy have focused on the ET as an anatomical landmark for the ICA in skull base surgery [7,8]. Abdel-Aziz et al. evaluated the prevalence of Carotid canal dehiscence within the bony portion of the ET [9]. Bergin et al. measured the distance between the 
cartilaginous ET and the ICA using CT scans [10]. Measurements were taken from the nasopharyngeal orifice of the ET to the ICA, but the surgically important distances between the ET and the ICA that decrease with progression toward the isthmus were not measured.

The present study was designed to establish the anatomical relationships between the endoscopically critical area along the full length of the cartilaginous ET and its closest association with the ICA. The surgeon's knowledge of this relationship is critically important for the avoidance of possibly severe complications in endoscopic ET surgery.

\section{Material and Methods}

Institutional review board approval was obtained from Tampere University Hospital, Tampere, Finland. All patient data were acquired from Tampere University Hospital's medical records database. In total, 229 MRI images were evaluated, in 129 cases there were artefacts or the resolution of the image was insufficient for assessment. Finally, 100 cases were included and both sides were evaluated.

The nasopharyngeal orifice of the ET (Figure 1) and the tympanic orifice of the bony ET (Figure 2) were marked in separate axial plane MRI images. Multiplanar reconstructions (MPR) were made along the length of each ET (Figure 3A). A straight line between these orifices was marked to represent the ET lumen (Figure 3B). The images were then rotated parallel to the line (Figure 4) to form sagittal oblique reconstruction (MPR) slices. The perpendicular distance 
between the line representing the ET lumen, and the ICA were measured at three points; A) cartilaginous and bony ET junctional point (Figure 4), B) mid cartilaginous ET point and C) the nasopharyngeal orifice of the cartilaginous ET (figures 3-4). The measurements were done by two separate raters. The first rater evaluated the all images and the second, senior rater, re-evaluated the images in 34 cases for inter-rater control.

The MRI examinations were performed with a 3T MRI scanner (Siemens Trio, Siemens Medical Solutions, Erlangen, Germany). A 12-channel head coil was used. The examinations were made for various clinical purposes, and none of the subjects had significant structural abnormalities on conventional MRI sequences. Two different imaging protocols were selected for this study: 1) Sagittal T2 Space sag P2 isotropic 0.9 (TR, 3200 ms; TE, 407ms; FOV, 230 x 230; matrix, 256×256; slice/gap 0.9/0.9 mm.) (43 patients). 2) High resolution T1 isotropic 0.9 gradient echo, IP prepared (time of inversion $900 \mathrm{~ms}$; TR $1900 \mathrm{~ms}$; TE 2,4 ms; Fov 230 x 230, matrix 246 x256, slice/gap 0.9mm/0.9mm.) (57 patients). Both of the selected protocols were found suitable for image analysis. The analysis was done using Philips Extended Brilliance ${ }^{\mathrm{T}}$ workspace (Koninklijke Philips Electronics N.V., Netherlands).

\section{Results}

The results of the measurements A, B and C for right and left ears are given in Table 1. For the junctional point, mean distances A were, for the right ear, 4.2 $\mathrm{mm}$ (standard deviation $1.8 \mathrm{~mm}$, range $1.6-10.4 \mathrm{~mm}$ ), and for the left ear, 4.3 
$\mathrm{mm}$ (standard deviation $1.8 \mathrm{~mm}$, range $1.2-8.5 \mathrm{~mm}$ ). For the midpoint of the cartilaginous Eustachian tube, distances B were, for the right ear, $24.5 \mathrm{~mm}$ (standard deviation $8.0 \mathrm{~mm}$, range $13.8-59.1 \mathrm{~mm}$ ), and for left ear, $25.5 \mathrm{~mm}$ (standard deviation $10.0 \mathrm{~mm}$, range 9.0 - $61.6 \mathrm{~mm}$ ). For the orifice of the cartilaginous Eustachian tube mean distances $C$ were, for the right ear, $61.9 \mathrm{~mm}$ (standard deviation $10.0 \mathrm{~mm}$, range $36.9-84.4 \mathrm{~mm}$ ), and for the left ear, 61.9 $\mathrm{mm}$ (standard deviation $9.4 \mathrm{~mm}$, range $34.3-78.2 \mathrm{~mm}$ ).

The inter-rater correlation of the two reviewers was evaluated as a mean of the difference between the values of two reviewers. The differences of the means in measure A was $0.4 \mathrm{~mm}$, in measure B $2.1 \mathrm{~mm}$ and in measure $\mathrm{C} 1.1 \mathrm{~mm}$.

Table 1. Average distances between the internal Carotid artery and the cartilaginous Eustachian tube at A) cartilaginous and bony ET junctional point, B) mid cartilaginous ET point and C) the nasopharyngeal orifice of the cartilaginous ET.

\begin{tabular}{lcccccc}
\hline & \multicolumn{3}{c}{ Right ear } & \multicolumn{3}{c}{ Left ear } \\
\hline Measure & A & B & C & A & B & C \\
\hline Mean (mm) & 4.2 & 24. & 61.9 & 4.3 & 25. & 61.9 \\
& & 5 & & & 5 & \\
Standard & 1.8 & 8.0 & 10.0 & 1.8 & 10. & 9.4 \\
deviation & & & & & 0 & \\
\hline
\end{tabular}




\section{Discussion}

Eustachian tube dilation, including balloon dilation, has received increasing attention as a safe and potentially effective surgical option for patients with Eustachian tube dilatory dysfunction. Surgical treatment for patulous Eustachian tube has also received some attention, although results have been modest [5]. In both situations, the surgery has focused on the cartilaginous portions of the ET and especially on the so-called area of the functional "valve". Poe et al have proposed that in diseases of the ET, the main focus should be in the functional valve area, located within the middle to upper portions of the cartilaginous ET over a length of about 10-15 mm [11].

To date, endoscopic approaches to the ET have been safe, but the close anatomical relationship of the ICA and the ET should be understood, particularly when surgical procedures may be carried up toward the isthmus and skull base. Severe complication including cerebral thrombosis and death has been reported in the past in the early experience with ET surgery [6]. The close anatomical relationship of these two structures has been reviewed in previous studies, but in most of them the point of view has been neurosurgical relationships with the bony portion of the ET.

Ozturk et al. used histologically prepared serial sections of temporal bones to investigate the perpendicular relationship between the ET lumen and petrous segment of the ICA [7]. In a series of 10 human temporal bone specimens, the mean distance between the ET and the ICA for the junctional point was $2.5 \mathrm{~mm}$, but the range in this small series was relatively large, $0.6-5.0 \mathrm{~mm}$. In our much larger material including 200 measurements, the perpendicular distance 
between the ET and the ICA at the junctional point was $4.3 \mathrm{~mm}$ with relatively large range (2-10 $\mathrm{mm})$. It seems that the narrowest distance is a bit longer than in Ozturk material, but the variation between patients can be even larger than Ozturk material. This finding of the large anatomical variation underlines the need for preoperative imaging and evaluation of the distance of the ET and the ICA.

Bergin et al. measured the distance of the ET and ICA using axial CT scans rather than MPR, which would provide the most accurate means for determining minimal distances [10]. Measurements were taken from the anterosuperior ET torus to the ICA from 200 patients. This study didn't describe the association between the ET and ICA along the whole distance of the cartilaginous ET. Mean distance from the anterosuperior ET torus to the ICA was $23 \mathrm{~mm}$. Abdel-Aziz et al. examined the relationships between the ET and the bony canal of the ICA from HR-CT scans of the temporal bone [9]. There were 284 patients in the study and they discovered carotid canal dehiscence into the ET in $6 \%$ of 284 patients. The anatomical relationship of the ICA and cartilaginous ET was not evaluated in their study.

Liu et al. researched the relationship between the ET and ICA by dissecting silicon-injected adult cadaveric heads using a lateral infratemporal fossa approach and an endoscopic endonasal approach [8]. The aim of their study was to establish the detailed anatomic relationships between the ET and the petrous (bony) segment of the ICA. Their study focused on the relationships between anatomical structures, including the ICA, with the ET during progressively superior levels of surgical dissection. Quantitative measurements were not made and the study focused on the bony portion of the ET more than the cartilaginous portion. A limitation of the study was that it included six patients 
(12 sides) such that the generalization of the results should be taken cautiously due to possible limited anatomical variation.

Endoscopic Eustachian tube surgery has been shown to be surgically feasible with high success rates for gaining adequate access and with a good safety record to date. There have been only minor complications reported in the literature including limited epistaxis, acute otitis media, tinnitus and subcutaneous emphysema. Severe complications including cerebral thrombosis and death have been reported only in the past, prior to the recent endoscopic experience. In our study the number of patients at 100 should be sufficient to demonstrate a representative variation in anatomy. We observed the relationship between the whole cartilaginous part of ET and ICA to understand the potential for risks posed by the location of ICA in the surgical treatment of the ET.

A limitation of this study was difficulty to visualize the location of the ET lumen on a MRI scan. Under normal conditions ET is closed and you can only see the bony isthmus and the nasopharyngeal orifice on a MRI scan. We assumed that ET locates on a straight line between these two points even if the tube is in reality angulated a little and the wide lumen is folded in rest position. The distance to the ICA is shorter than measured when the lumen is open while you put the catheter into the ET or during the endoscopic surgery. Further researches such measurements should be performed on open ET in order to more detailed information about safety during operation. This study did not include subjects with craniofacial or skull base anomalies. It is known that velocardio-facial syndrome patients may have a highly aberrant course of the ascending ICA that can bring it into close proximity with the tonsillar fossa and 
adenoid. Patients with syndromic conditions should be carefully evaluated for their potentially highly individualized anatomy.

\section{Conclusion}

In patients without congenital craniofacial anomalies, performance of surgical treatment near the orifice of the cartilaginous ET is expected to present a safe distance from the ICA. The potential for complications increases while progressing superiorly towards the cartilaginous and bony ET junctional point because the ICA gets increasingly close to the ET. It then shares a bony wall within the temporal bone and can become dehiscent within the bony portion of the ET.

\section{Authors have no potential conflict of interest.}

\section{Recerences}

1. Browning G, Gatehouse S (1992) The prevalence of middle ear disease in the adult British population. Clin Otolaryngol Allied Sci 17:317-21.

2. Kujawski O, Poe D (2004) Laser Eustachian tuboplasty. Otol Neurotol 25:1-8. 
3. Metson R, Pletcher SD, Poe DS (2007) Microdebrider eustachian tuboplasty: A preliminary report. Otolaryngol Head Neck Surg 136:422-7.

4. Silvola J, Kivekäs I, Poe D (2014) Balloon Dilation of the Cartilaginous Portion of the Eustachian Tube. Otolaryngol Head Neck Surg 151:125-130.

5. Hussein A, Adams A, Turner J (2015) Surgical management of Patulous eustachian tube: A systematic review. Laryngoscope 125:2193-8.

6. O'Connor A, Shea J (1981) Autophony and the patulous eustachian tube. Laryngoscope 91:1427-35.

7. Ozturk K, Snyderman C, Gardner P, Fernandez-Miranda J (2012) The Anatomical Relationship Between the Eustachian Tube and Petrous Internal Carotid Artery. Laryngoscope 122: 2658-2662.

8. Liu J, Pinheiro-Neto C, Fernandez-Miranda J, Snyderman C, Gardner P, Hirsch B, Wang E (2014) Eustachian tube and internal carotid artery in skull base surgery: an anatomical study. Laryngoscope 124:2655-64.

9. Abdel-Aziz T, Schröder S, Lehmann M, Gehl HB, Ebmeyer J, Sudhoff H (2014) Computed tomography before balloon Eustachian tuboplasty--a true necessity? Otol Neurotol 35:635-8.

10. Bergin M, Bird P, Cowan I, Pearson J (2010) Exploring the Critical Distance and Position Relationships Between the Eustachian Tube and the Internal Carotid Artery. Otol Neurotol 31:1511-1515.

11. Poe D, Pyykkö I, Valtonen H, Silvola J (2000) Analysis of eustachian tube function by video endoscopy. Am J Otol 21:602-7. 


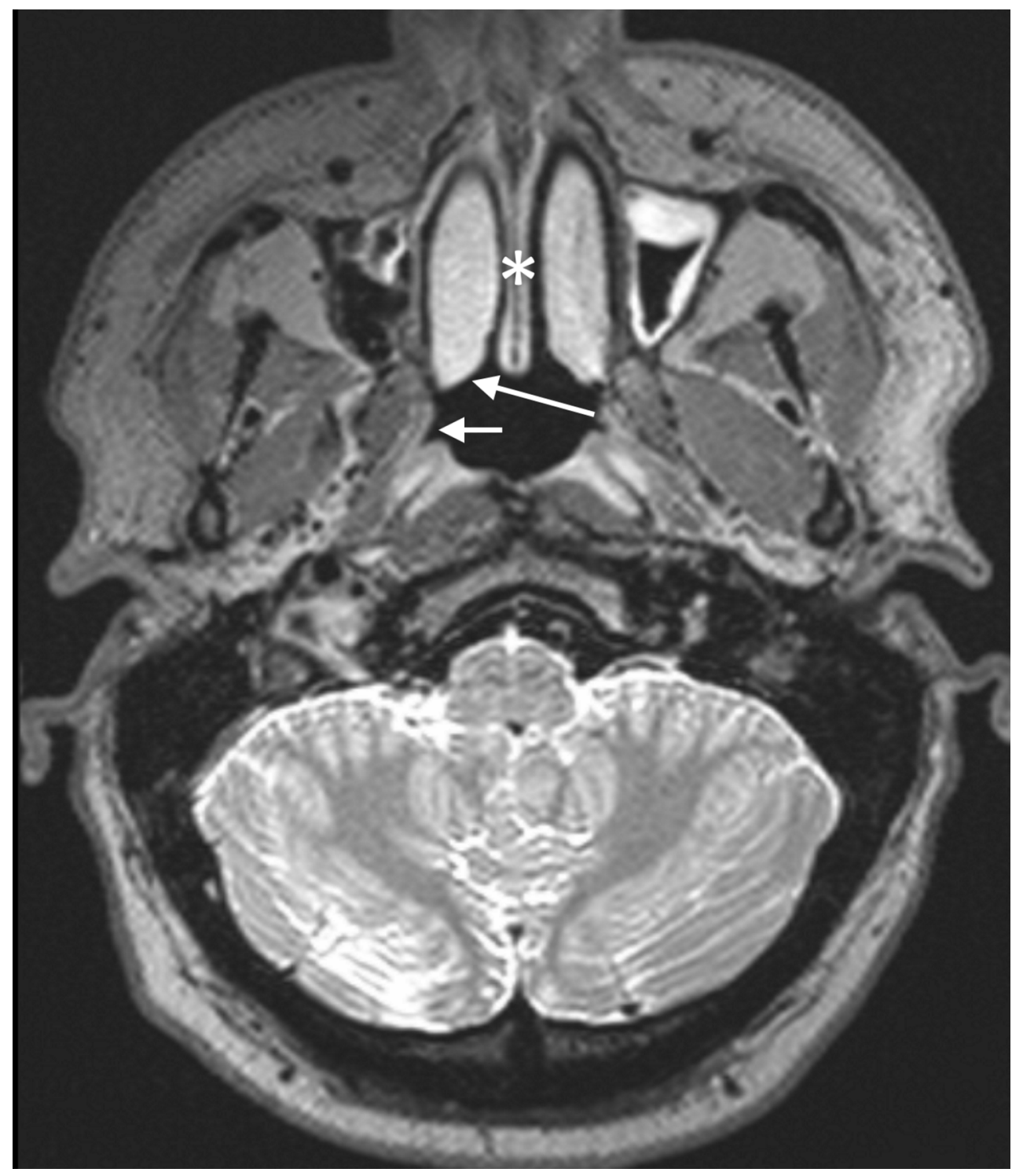

Figure 1. Axial MRI image of the cartilaginous Eustachian tube, where short arrow indicates the nasopharyngeal orifice of the cartilaginous ET. Long arrow indicates the posterior end of the inferior turbinate and asterisk point the nasal septum. 


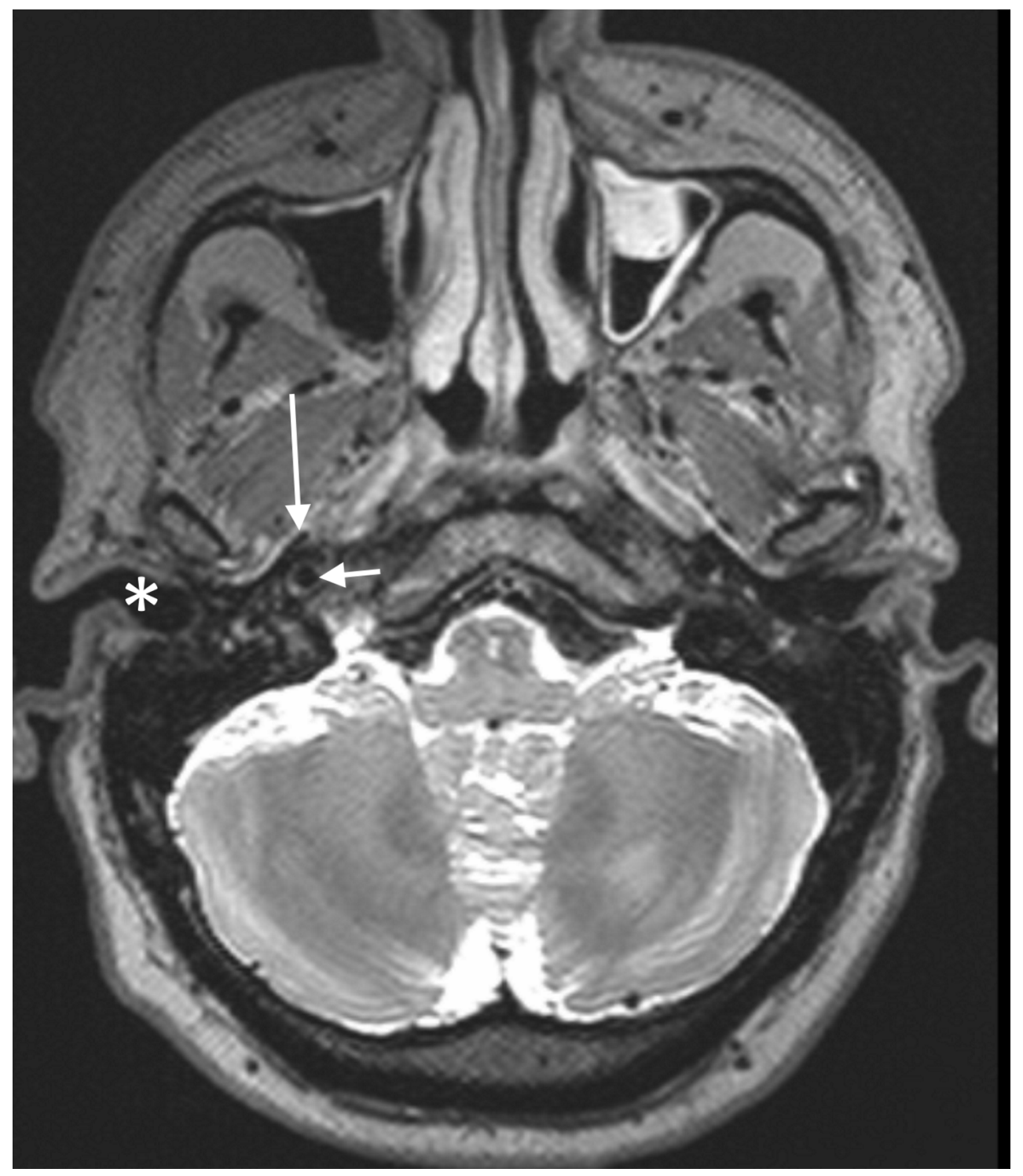

Figure 2. Axial MRI image of the bony Eustachian tube, where short arrow shows internal carotid artery, long arrow shows the bony lumen of the ET, and an asterisk shows the external auditory canal. 


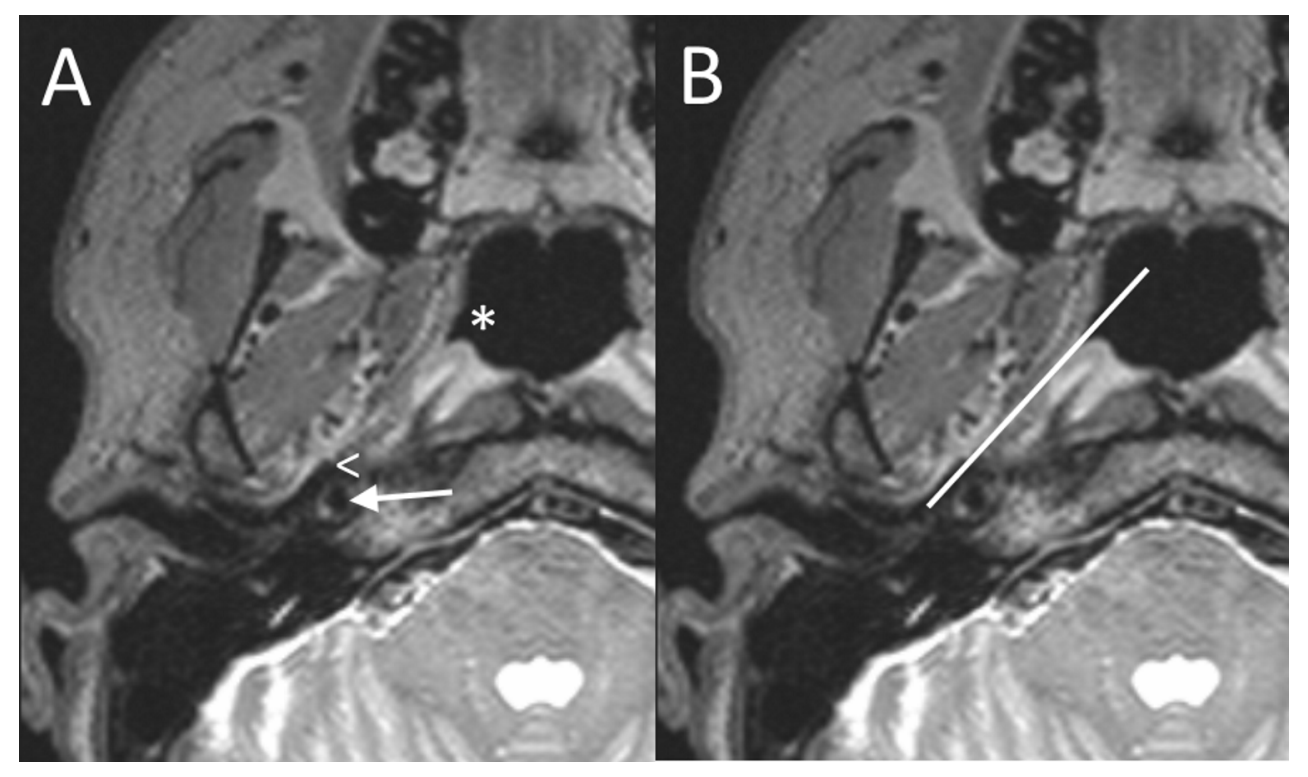

Figure 3. A) The nasopharyngeal orifice of the ET (asterisk) and the tympanic orifice of the bony ET (arrowhead) were marked in separate axial plane MRI images and multi-planar reconstructions (MPR) were made along the length of ET. Internal carotid artery marked with the short arrow. B) A straight line between these orifices was marked to represent the ET lumen. 


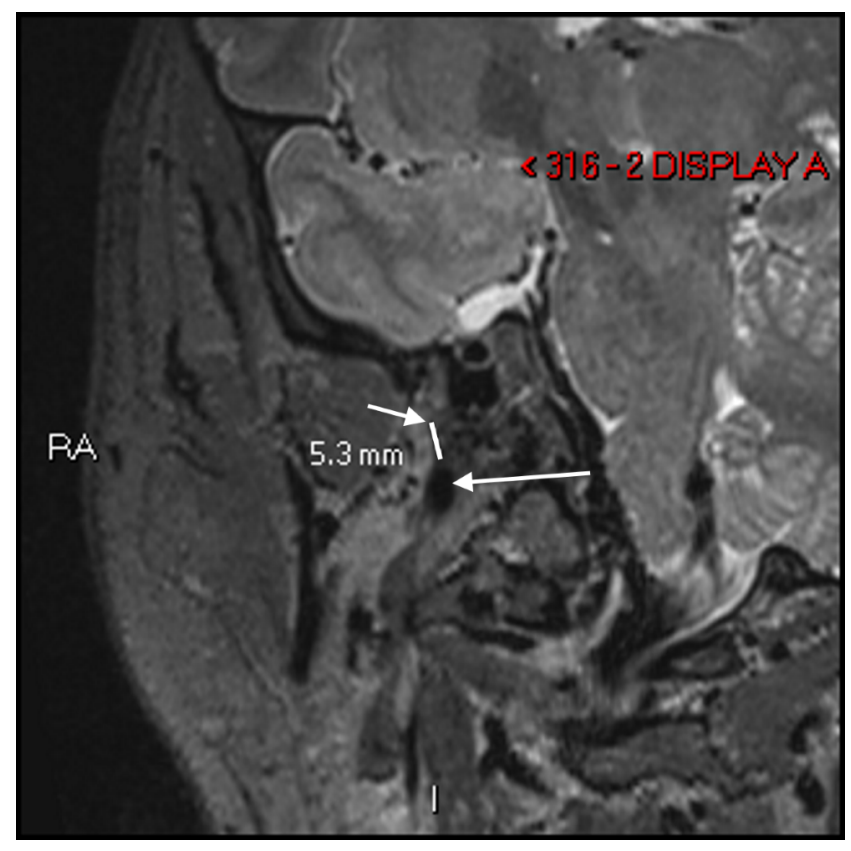

Figure 4. The images were then rotated parallel to the line (figure 3B) to form sagittal oblique reconstruction (MPR) slices. The perpendicular distance (white line, $5.3 \mathrm{~mm}$ in this case) between the line representing the ET lumen (short arrow), and the ICA (long arrow) were measured at the cartilaginous and bony ET junctional point. 